The Cult of Pharmacology 
Duke University Press Durham + London 2006 


\section{The Cult of Pharmacology}

How America Became the World's Most Troubled Drug Culture 
๑) 2006 Duke University Press / All rights reserved

Printed in the United States of America on acid-free paper $\infty$

Designed by Jennifer Hill / Typeset in Galliard by Keystone Typesetting, Inc.

Library of Congress Cataloging-in-Publication Data appear on the last printed page of this book. 